\title{
Human Creatine Kinase-B complementary DNA \\ Nucleotide Sequence, Gene Expression in Lung Cancer, and Chromosomal Assignment to Two Distinct Loci
}

Frederic J. Kaye, O. Wesley McBride,* James F. Battey, Adi F. Gazdar, and Edward A. Sausville

National Cancer Institute-Navy Medical Oncology Branch and ${ }^{*}$ Laboratory of Biochemistry, National Cancer Institute, National Institutes of Health, and Naval Hospital, Bethesda, Maryland 20814

\begin{abstract}
Using a small cell lung cancer (SCLC) cDNA library, we obtained clones for the creatine kinase-B (CK-B) gene and determined the nucleotide sequence for the protein coding and $3^{\prime}$ untranslated region ( $3^{\prime}$ UT). The human translated protein spans 381 residues and the amino acid homology with rabbit CK-B is $>98 \%$. We have demonstrated that a nucleic acid probe encompassing the protein coding region will also hybridize to CK-M sequences while a probe derived from the $3^{\prime}$ UT region is CK-B specific. When a B-isoenzyme specific sequence is hybridized to Eco RI cut genomic DNA, two independent restriction fragment polymorphisms are detected. We have subsequently localized these two CK-B homologous sequences to chromosomes 14932 and 16. Finally, we show that increased levels of CK-B seen in SCLC are not accompanied by gene amplification or rearrangement, but reflect a greatly enhanced level of CK-B specific mRNA that is not seen in non-SCLC lines thus far examined.
\end{abstract}

\section{Introduction}

The creatine kinases are a family of enzymes with a highly conserved protein sequence, which are involved in the maintenance of ATP at sites of cellular work (1). Three cytoplasmic (nonmitochondrial) isoenzymes of creatine kinase (CK) ${ }^{1}$ are readily identified in human tissue. These isoenzymes are dimeric molecules with two dissociable subunits designated as M- (muscle) or B- (brain) type that can reassociate to form the electrophoretically distinct $\mathrm{MM}, \mathrm{BB}$, or $\mathrm{MB}$ isotypes. Recent investigations have determined that the amino acid sequences of these two subunits are encoded by distinct genes $(2,3)$. Despite the existence of CK-M or CK-B cyclic complementary DNA (cDNA) clones from several animal species (2-8), the basis for the tissue specific expression of these isoenzymes is not known.

Elevated levels of the BB isoenzyme of CK have been detected in tumor samples obtained from patients with small cell lung cancer (SCLC) (9). Marked elevation of the BB isoenzyme of $\mathrm{CK}$, as measured with a radioimmunoassay, was previously

Address reprint requests to Dr. Kaye, NCI-Navy Medical Oncology Branch, Building 8, Room 5101, Naval Hospital, Bethesda, MD 20814.

Portions of this work were presented at the Annual Meeting of the American Society for Clinical Investigation, Washington, DC, May 1986, and published in abstract form (1986. Clin. Res. 34:691A).

Received for publication 3 September 1986.

1. Abbreviations used in this paper: $\mathrm{CK}$, creatine kinase; RFLP, restriction fragment length polymorphism; SCLC, small cell lung cancer; SM, skeletal muscle; $3^{\prime}$ UT, $3^{\prime}$ untranslated region.

The Journal of Clinical Investigation, Inc.

Volume 79, May 1987, 1412-1420 noted in 49/50 cell lines established in our laboratory from patients with SCLC (10). In contrast, CK-BB levels in non-SCLC lines were considerably lower or negligible in most cases. The level of this enzyme thus is a reliable marker of SCLC and may be of functional importance in determining aspects of the small cell phenotype, including the neuroendocrine features unique to this tumor (11).

In this study we have cloned and sequenced a cDNA copy of the messenger (mRNA) for the human B-isoenzyme of CK from a cDNA library prepared from a SCLC cell line. We have demonstrated that the coding region of this clone will crosshybridize with both $\mathrm{M}$ - and B-type isoenzymes. Using a prepared fragment from the $3^{\prime}$ untranslated region as a CK-B-specific sequence, we have then examined expression in RNA of the creatine kinase gene in cell lines representing different histologic types of lung cancer. We have also investigated the arrangement of this gene in genomic DNA. Two independent, high-frequency Eco R1 polymorphic sites were identified that we relate to two CK-B specific sequences located on different chromosomes.

\section{Methods}

Cell lines and cell culture. The SCLC cell lines were established from clinically derived specimens by propagation in selective media as described previously (10). Human promyelocytic cell line HL60 was obtained from J. Trepel, National Cancer Institute, Bethesda, MD.

Isolation of cDNA and genomic clones. A SCLC cDNA library in lambda gt 10 was constructed from poly (A)-selected RNA isolated from cell line $\mathrm{NCI}-\mathrm{H} 378$, as described previously (12), and was screened with a cloned rabbit CK-B cDNA probe described by Pickering and Schimmel (2) and kindly provided by G. Daouk. Several non-full length human cDNA clones were isolated, the largest measuring $1.1 \mathrm{~kb}$. Additional $5^{\prime}$ cDNA sequence was obtained by primer extension as described by Cooper and Ordahl (13). Genomic CK-B specific clones were isolated by screening a partial Mbo I-digested human placental library in Charon phage 28A with a subclone from the most $5^{\prime}$ region of the human cDNA sequence. Nucleotide sequence of both strands of cDNA, employing the Sanger dideoxynucleotide chain termination method, were obtained with overlapping M13 phage clones $(14,15)$. Due to the lack of useful restriction enzyme sites toward the $3^{\prime}$ end of the cDNA clones, overlapping Bal 31 digested M13 phage clones were generated for sequencing (16).

Nucleic acids. DNA, total RNA, and poly (A)-selected RNA were extracted from the human lung cancer cell lines as previously described (17-19). In addition, total RNA was extracted from human skeletal muscle obtained at autopsy. DNA and RNA were transferred to nitrocellulose after electrophoresis through nondenaturing or formaldehyde containing gels, respectively $(20,21)$. Hybridization of nitrocellulose filters with [ $\left.{ }^{32} \mathrm{P}\right] \mathrm{dCTP}$ nick-translated DNA fragments were performed as described (22).

RNAase protection assay. $10 \mu \mathrm{g}$ of total RNA from either human skeletal muscle or a lung cancer cell line was allowed to hybridize 12$15 \mathrm{~h}$ with a ${ }^{32} \mathrm{P}$-labeled RNA probe prepared by using the $\mathrm{pSP} 6$ vector system (Promega Biotec, Madison, WI) in the appropriate orientation to transcribe a single stranded molecule complementary to mRNA (23). 
The hybridization mix was then digested with RNAase A resulting in complete digestion of all single-stranded regions. Conditions for hybridization and digestion with RNAase were as previously described (24, 25 ). The protected regions of our RNA probe were identified by denaturing 6\% acrylamide electrophoresis and autoradiography.

Chromosomal mapping. Localization of the CK-B gene was performed by examination of DNA extracted from a panel of human-rodent somatic cell hybrids. These methods have been previously described in detail (26).

\section{Results}

Human $C K-B$ CDNA sequence. The restriction map and sequencing strategy for the human CK-B cDNA is shown in Fig. 1. The cDNA sequence of the human CK-B protein coding and $3^{\prime} \mathrm{UT}$ is presented in Fig. 2. As demonstrated from prior sequence analysis in different animal species (2-8), there is remarkable evolutionary conservation in the primary structure of the coding region of the B-subunit from human and rabbit sources. There is a single long open reading frame, in both human and rabbit cDNAs, beginning with an ATG start codon at position 9 in Fig. 2 and spanning 1,143 base pairs (bp) to the termination codon at position 1,152 . Nucleotide homology between species is in excess of $94 \%$. In addition, as most nucleotide changes are silent, homology between species of the translated 381 amino acid protein is $>98 \%$. Comparison of the sequence of B- with M-isoenzymes reveals a decreased, but still substantial, homology within stretches of the protein coding region (Fig. 2). In contrast, the $3^{\prime}$ UT contains no sequence conservation between the brain and muscle isoenzymes yet persistent interspecies homology between human and rabbit brain sequences. Thus a DNA sequence confined to the $3^{\prime} \mathrm{UT}$ region could serve as a CK-B specific probe. Accordingly, a $115 \mathrm{bp}$ fragment from the $3^{\prime} \mathrm{UT}$ of our human cDNA clone (nucleotide position 1142 to 1257) was subcloned.

Tissue specificity of the $C K-B$ probe. To determine the specificity of the subcloned probe from the $3^{\prime}$ UT, total RNA was prepared from human psoas muscle obtained at autopsy or from a SCLC cell line. As shown in Fig. $3 \mathrm{~A}$, a 1.1-kb fragment designated pCK4, which encompasses over three-quarters of the CK-B protein coding sequence (from nucleotide position 270 to the poly-A tail), hybridizes to a $1.6-\mathrm{kb}$ species present in muscle RNA. In contrast, when equal amounts of total RNA isolated from SM is hybridized to the $3^{\prime}$ UT-derived CK-B specific probe, no signal is seen even after a prolonged exposure as shown. To prove further the isoenzyme specificity of the $3^{\prime}$ untranslated fragment, a RNAase protection assay was performed as seen in

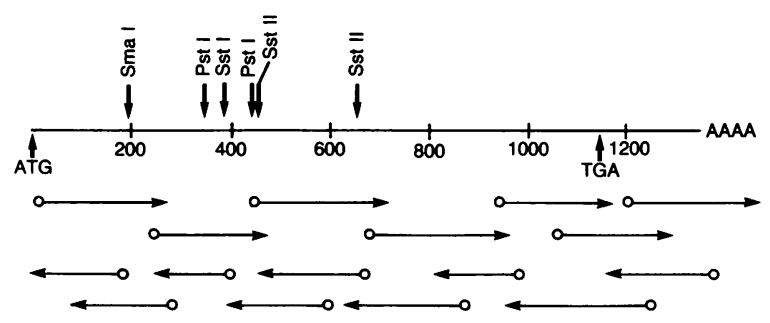

Figure 1. Restriction map, nucleotide coordinates, and sequencing strategy for the human CK-B cDNA. Due to the lack of useful restriction enzyme sites toward the $3^{\prime}$ end of the cDNA, overlapping Bal 31 digested M13 phage clones were generated for sequencing (16). In addition, confirmatory sequence data was obtained 5 ' of the Sst I site with overlapping CK-B genomic clones.
Fig. 3 B. Total RNA isolated from SCLC cell line NCI-H592 protects an $\sim 115$ bp antisense species derived from the $3^{\prime}$ UT from RNAase digestion. In contrast, RNA from skeletal muscle does not protect any portion of the probe from digestion. The three closely spaced bands in the SCLC RNA lane (at 117, 114, and $111 \mathrm{bp}$ ) represent digestion by RNAase of several nucleotides from one end of our probe and do not reflect the presence of differing mRNA species. This was established by hybridizing the antisense RNA probe with six independently isolated CK-B cDNA clones followed by RNAase digestion. The autoradiographic pattern from each RNA:DNA hybrid was identical to that depicted in Fig. $3 B$ (data not shown). Thus, we conclude by sequence analysis, Northern blot, and RNAase protection experiments that our human clones are B-isoenzyme derived and can be used to explore tissue specific expression of this isoenzyme gene.

$C K$ gene expression in lung cancer. Fig. 4 examines the expression of the CK gene in several lung cancer cell lines. All SCLC cell lines screened to date express abundant quantities of a 1.6-kb CK message. In addition, in RNA from several cell lines higher molecular weight species are apparent, perhaps precursors to the mature mRNA. In contrast to the easily detected CK-B mRNA in SCLC, non-SCLC cell lines NCI-H125 and $\mathrm{NCI}-\mathrm{H} 23$ have markedly decreased, but not absent, expression of CK. An additional non-SCLC cell line, NCI-H460, which has previously been shown to contain neurosecretory granules (A. F. Gazdar, unpublished observation), has an intermediate level of expression. Fig. 5 shows that, using a $5^{\prime}$ cDNA probe overlapping the coding region that would detect CK-B or CK$M$ species, total and poly (A)-selected RNA from SCLC cell lines NCI-H82 and NCI-H592 again express an abundant 1.6$\mathrm{kb}$ message. In contrast, equal amounts of total and poly (A)selected RNA from rapidly dividing undifferentiated HL60 cells do not show any expression of CK-B. This result implies that expression of CK-B is not merely correlated with rapid cell growth, as HL60 cells grow as or more rapidly than the lung cancer-derived cell lines. In experiments not shown, it was found that induction of HL60 differentiation to a monocytic phenotype by dibutyryl cAMP was not accompanied by a significant increase in $\mathrm{CK}$ gene expression.

Analysis of CK-B specific RNA expression of a panel of tumor cell lines using total RNA and the antisense $3^{\prime}$ untranslated probe is shown in Fig. 6. All SCLC cell lines screened contain large amounts of CK-B specific mRNA. In contrast, total RNA extracted from the promyelocytic cell line HL60 or from lung cancer cell lines derived from adenocarcinoma, large cell, adenosquamous or squamous carcinoma do not offer appreciable protection of the CK-B specific probe. Examination of the RNA samples, by ethidium bromide-stained gel electrophoresis, showed no differences in the amount or quality of the RNA preparations used from the different cell lines (data not shown). We therefore conclude that the low levels of CK-B activity in non-SCLC derived tumors or cell lines (9) reflect a decrease in the abundance of CK-B mRNA in these different histologic categories of human lung cancer.

Analysis of genomic DNA and evidence for two CK-B genes. To explore the basis for enhanced CK-B gene expression in SCLC, an effort was made to localize this gene and to examine whether amplification or rearrangement of this locus had occurred. Genomic DNA digested with Eco RI from several lung cancer cell lines was examined with the pCK4 probe that we had previously shown to hybridize with both CK-M and CK-B 
- H-B CCGCCGCCATGCCCTTCTCCAACAGCCACAACGCACTGAOAGCTGCGCTTCCCGGCCGAGGACGAGTTCCCCGACCTGAGCGCCCACAACAACCACATGGC R-M

H-B CAAGgTGCTGACCCCCGAGCTGTACGCGGAGCTGCGCGCCAAGAGCACGCCGAGCGGCTTCACGCTGGACGACGTCATCCAGACAGGCGTGGACAACCCG R-B - - AH-B aLysValleuThrProGluLeuTyrAlaGluLeuArgAlaLysSerThrProSerGlyPheThrLLuAspAspValIleGInThrGlyValAspAsnPro R-M Asp MetAsp Lyslys Asp Glu

200 H-B GGCCACCCGTACATCATGACCGTGGGCTGCGTGGCGGGCGGCGAGGAGTCCTACGAAGTGTTCAAGGATCTCTTCGACCCCATCATCGAGGACCGGCACG R-B H-B GlyHisProTyrIleMetThrValGlyCysValAlaGlyGlyGluGluSerTyrGluValPheLysAspLeuPheAspProIleIleGluAspArgHisG

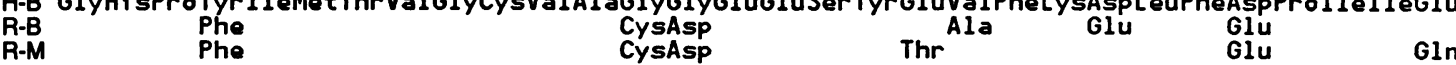

300 H-B GCGGCTACAAGCCCAGCGATGAGCACAAGACCGACCTCAACCCCGACAACCTGCAGGGCGGCGACGACCTGGACCCCAACTACGTGCTGAGCTCCGGGGT R-B H-B lyGlyTyrLysProSerAspGluHisLysThrAspLeuAsnProAspAsnLeuGlnGlyGlyAspAspLeuAspProAsnTyrValLeuSerSerGlyVa $\begin{array}{lllll}\text { R-B } & \text { Phe HisGlu Lys Lys His Arg }\end{array}$

400 H-B GCGCACGGGCCGCAGCATCCGTGGCTTCTGCCTCCCCCCGCACTGCAGCCGCGGGGAGCGCCGCGCCATCGAGAAGCTCGCGGTGGAAGCCCTGTCCAGC R-B H-B IArgThrGlyArgSerI leArgGlyPheCysLeuProProHi sCysSerArgGlyGluArgArgAlaI leGluLysLeuAlaValGluAlaLeuSerSer $\begin{array}{lllll}\text { R-B } & \text { Lys TyrThr } & \text { Val } & \text { Ser Asn }\end{array}$

500 H-B CTGGACGGCGACCTGGCGgGCCGATACTACGCGCTCAAGAGCATGACGGAGGCGGAGCAGCAGCAGCTCATCGACGACCACTTCCTCTTCGACAAGCCCG R-B R-M - - ACG---GT-CAA---GA-GH-B LeuAspGIyAspLeuAlaGlyArgTyrTyrAlaLeuLysSerMetThrGluAlaGluGinGinglnLeuI leAspAspHi sPheLeuPheAspLysProV R-M Thr GluPhelys Lys Pro Gln

600 H-B TGTCGCCCCTGCTGCTGGCCTCGGGCATGGCCCGCGACTGGCCCGACGCCCGCGGTATCTGGCACAATGACAATAAGACCTTCCTGGTGTGGGTCAACGA R-B H-B alSerProLeuLeuLeuAlaSerGlyMetAlaArgAspTrpProAspAlaArgGlyIleTrpHisAsnAspAsnLysThrPheL euValTrpValAsnG1 H-B
R-B Ser

700 H-B GGAGGACCACCTGCGGGTCATCTCCATGCAGAAGGGGGGCAACATGAAGGAGGTGTTCACCCGCTTCTGCACCGGCCTCACCCAGATTGAAACTCTCTTC R-B R-M uGluAspHisLeuArgValIleSerMetGlnLysGlyGlyAsnMetLysGluValPheThrArgPheCysThrGlyLeuThrGlnIleGluThrLeuPhe

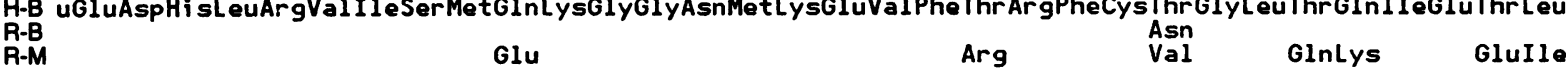

800 H-B AAGTCTAAGGACTATGAGTTCATGTGGAACCCTCACCTGGGCTACATCCTCACCTGCCCATCCAACCTGGGCACCGGGCTGCGGGCAGGTGTGCATATCA R-B -

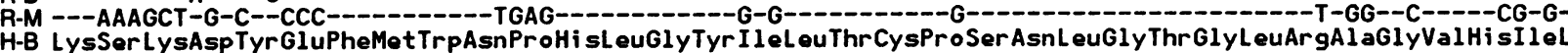

R-M LysAlaGlyHisPro

Glu

Val

Gly

Val

900 H-B AGCTGCCCAACCTGGGCAAGCATGAGAAGTTCTCGGAGGTGCTTAAGCGGCTGCGACTTCAGAAGCGAGGCACAGGCGGTGTGGACACGGCTGCGGTGGG H-B AGCTGCCCAACCTGGGCAAGCATGAGAAGTTCTCGGAGGTGCTTAAGCGGCTGCGACTTCAGAAGCGAGGCACAGGCGGTTGGACACGGCTGCGGTGG R-M ysLeuProAsnLeuGlyLysHi sGluLysPheSerGluValLeuLysArgLeuArgLeuGInLysArgGlyThrGlyGlyValAspThrAlaAlaValGI H-B ysleuProAsnLeuGlyLyshisGluLysPheSerGluValleulysAr
R-B His Gli Ger Pro Glu Ile Thr

1000 H-B CGGGGTCTTCGACGTCTCCAACGCTGACCGCCTGGGCTTCTCAGAGGTGGAGCTGGTGCAGATGGTGGTGGACGGAGTGAAGCTGCTCATCGAGATGGAG R-B H-B yGlyValPheAspVaiSerAsnAlaAspArgLeuGlyPheSerGluValGluLeuValGInMetVaiValAspGlyVallysLeuLeuIleGluMetGlu
R-M Ser
Ile
Ser
Gln Leu
MetVal

1100 H-B CAGCGGCTGGAGCAGgGCCAGGCCATCGACGACCTCATGCCTGCCCAGAAAIGAGACCCGGCCCACACCCGACACCAGCCCTCGTGCTTCCTAACTTATT R-B -M A- AA-

H-B GlnArgLeuGluGlnGlyGInAlaI leAspAspLeuMetProAlaGlnLysTer
P-M
Lys Ser
MetIle

1200 H-B GCCTGGGCAGTGCCCACATGCACCCCTGATGTTGCCCGTCTGGCGAGCCCTTAGCCTTGCTGTAGAAGGACTGTCCGTCACCCTTGGTAGAGTTTATTTT H-B R-M CG-A-C--GCGCGG-C-CG-GGG-T-G-GT-CCAG-CAA--GCCC-GTCGTCTGCGT-CTGGCC-ATGAAA-G-C--C-T-ACACCTCGC-G-CCCGG

1300 H-B TTTGATGGCTAAGATACTGCTGATGCTGAAATAAACTAGGGTTTTGGCCTGCAAAAAAAA

R-M AGCTCC-C-C-CCTCCGGAGCACCTCCTG-CGGCTGGC--GGGGGGGGT-GGCTCCCGGCGTGTCTGGAGCGGGGCTTTTTCCCCACGCAAAGCAGT R-M GAATAAAAGCAGCGGCGGCCTTAAAAAAAA

Figure 2. The nucleotide and amino acid sequence of the human $\mathrm{CK}$ B cDNA (H-B) is shown on the first and fourth line of each set, respectively. The second and fifth line in each set represent the previously sequenced rabbit CK-B cDNA (R-B) and the third and sixth line represent the rabbit CK-M CDNA (R-M) sequence for comparison (2). The first $11 \mathrm{bp}$ of the human cDNA coding sequence, overlined in the figure, were obtained with an overlapping CK-B genomic clone and, as shown, there is complete nucleotide agreement with the rabbit CKB cDNA coding region. The stop codon for the human translated protein is enclosed in a box at position 1152 followed by a 198 bp 3' untranslated region. A tract of adenylate residues commences at position $1352,17 \mathrm{bp} 3^{\prime}$ of a polyadenylation consensus site. 


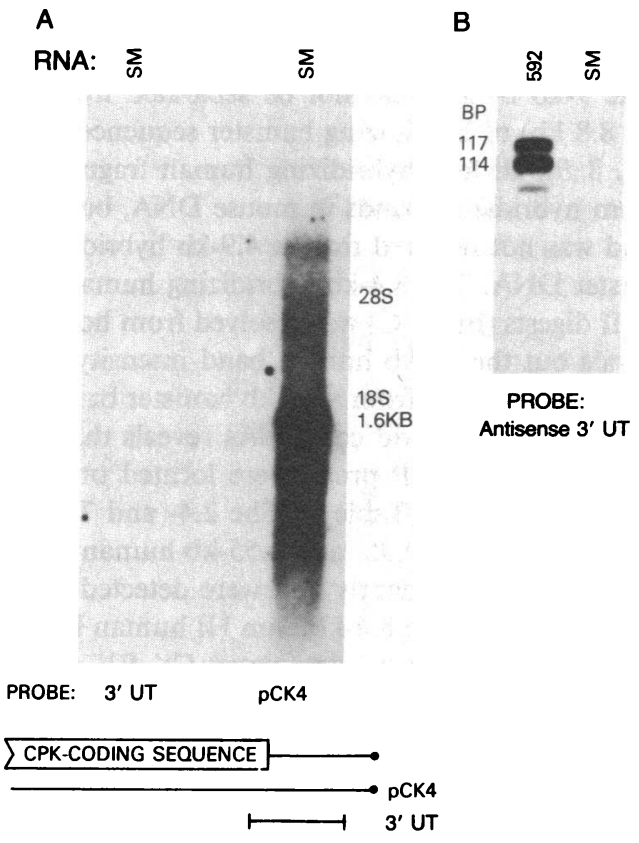

Figure 3. (A) Tissue specificity of the CK-B probe. Northern blot analysis. $10 \mu \mathrm{g}$ of total RNA isolated from human skeletal muscle, designated as SM, were transferred to nitrocellulose filter after electrophoresis. The right lane was probed with the prepared insert of pCK4 (nucleotide position 270 to the poly-A tail as seen in Fig. 2) and the left lane with a fragment from the $3^{\prime}$ untranslated ( $3^{\prime}$ UT) region (position 1142 to 1257 as seen in Fig. 2). (B) RNAase protection assay. The undigested anti-sense $3^{\prime}$ UT probe spans 165 bp as it contains a stretch of linker nucleotides at both ends of the probe. Hybridization of CK-B mRNA with this anti-sense probe should protect $115 \mathrm{bp}$.

sequences (Fig. $7 \mathrm{~A}$ ). A 27-kb band and two independent, high frequency Eco RI restriction fragment length polymorphisms (RFLP) one pair at 17 and $13 \mathrm{~kb}$ and the other at 7.5 and 5.4 $\mathrm{kb}$, are observed in the population of human DNAs examined. We have further investigated these Eco RI RFLPs with an ad- ditional panel of 23 human DNAs, and have calculated the allelic frequency of the 17 - and $13-\mathrm{kb}$ bands at 0.5 and the frequency of the 7.5 - and $5.4-\mathrm{kb}$ alleles at 0.15 and 0.85 , respectively. We have, in addition, digested normal human genomic DNA (from placenta and spleen) along with similarly prepared DNA from several lung cancer specimens and have not found differences in copy numbers of either of the hybridizing bands for CK-B (data not shown). There is, therefore, no evidence for either rearrangement or amplification of the CK gene in SCLC despite extensive evidence of enhanced expression. As seen in Fig. 7 B, the $3^{\prime}$ untranslated probe specific for CK-B fails to recognize the 27-kb band, but still hybridizes to both Eco RI polymorphisms (Fig. 7 B). Restriction endonuclease mapping of four independently isolated CK-B genomic clones excludes the possibility of an Eco R1 site within a potential intron in the $3^{\prime}$ UT (data not shown). Several small, nonoverlapping probes from the $5^{\prime}$ region of the CK-B gene also hybridized to both polymorphisms (data not shown). This strongly suggests the presence of two specific CK-B related sequences in the human genome.

Human chromosomal localization of $C K-B$ hybridizing sequences. To examine this point directly, human, mouse, and Chinese hamster genomic DNAs were digested with eight different restriction endonucleases, size fractionated by agarose $(0.7 \%)$ gel electrophoresis, transferred to nylon membranes, and hybridized with human CK-B cDNA probes. A series of hybridizing fragments was detected in each lane after autoradiography, and some hybridizing human bands were not resolved from homologous mouse or hamster bands in each of these digests. Neither of the two polymorphic CK-B hybridizing human bands in Eco R1 digests was resolved from homologous bands in hamster and mouse digests (data not shown). Most of the human fragments detected with the CK-B probe, however, were resolved from cross-hybridizing rodent sequences in Hind III, Pst I, and Bam HI digests (Fig. 8). DNAs from a panel of humanhamster and human-mouse hybrids were digested with each of these three restriction endonucleases and analyzed for the presence of specific human CK-B fragments by Southern hybridization and representative results are shown (Fig. 8).

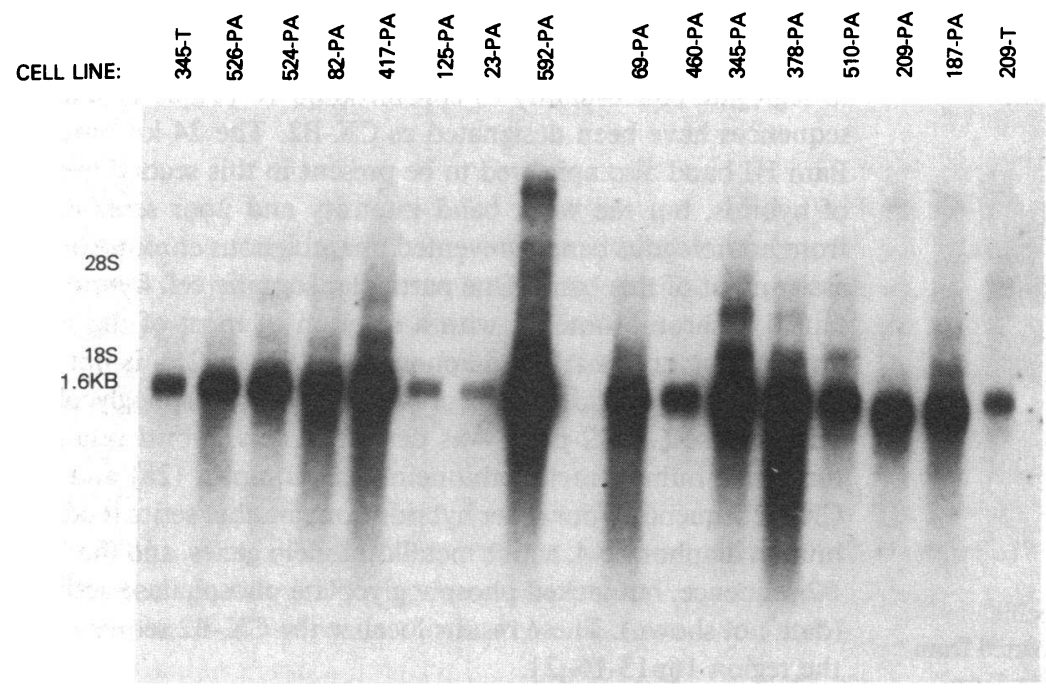

PROBE: SCLC-derived pCK4

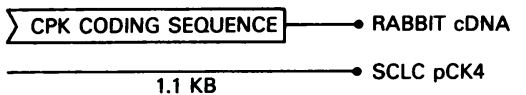

Figure 4. RNA expression in lung cancer cell lines. The two outer lanes in this figure represent $10 \mu \mathrm{g}$ of total RNA used as size markers. In the remaining lanes $2 \mu \mathrm{g}$ of lung cancer-derived poly (A)-selected RNA were loaded. The cell lines 23,125 , and 460 were isolated from patients with non-SCLC. The other cell lines in this figure originated from patients with SCLC. Exposure = XAR-5 film with an intensifying screen at $-70^{\circ} \mathrm{C}$ for $16 \mathrm{~h}$. 


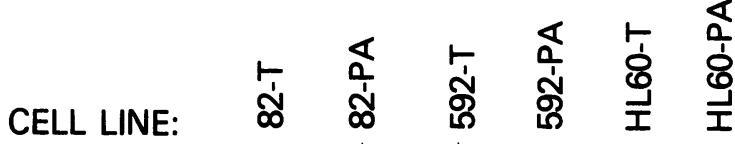

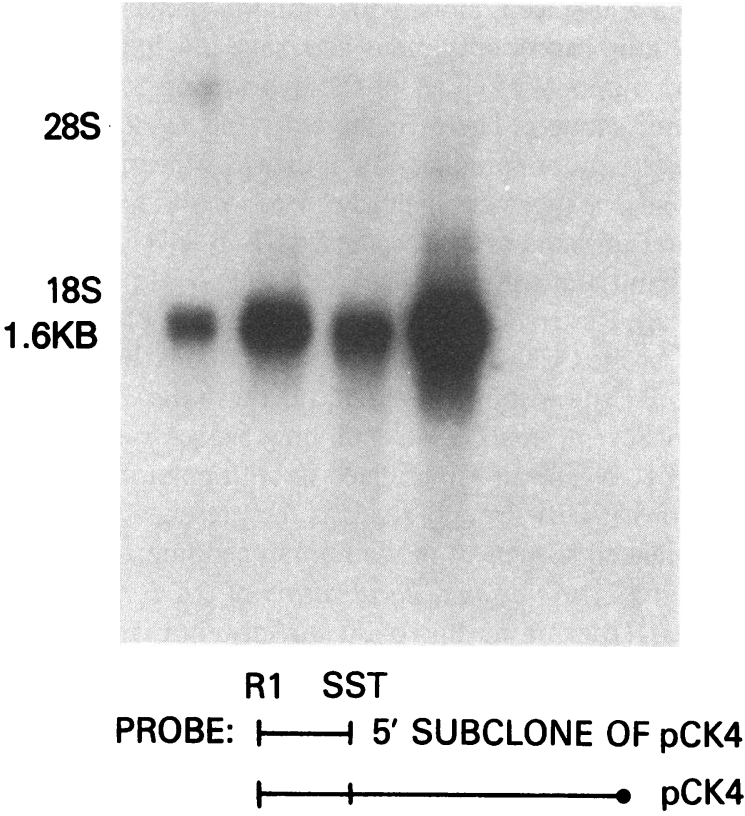

Figure 5. Negligible CK expression in undifferentiated HL60 cells. 10 $\mu \mathrm{g}$ of total (T) or $2 \mu \mathrm{g}$ of poly (A)-selected (PA) RNA from two SCLC cell lines (82 and 592) and from HL60 cells were examined for CK transcripts. The probe is a linker-Eco RI to Sst I fragment from the $5^{\prime}$ coding region of pCK4.

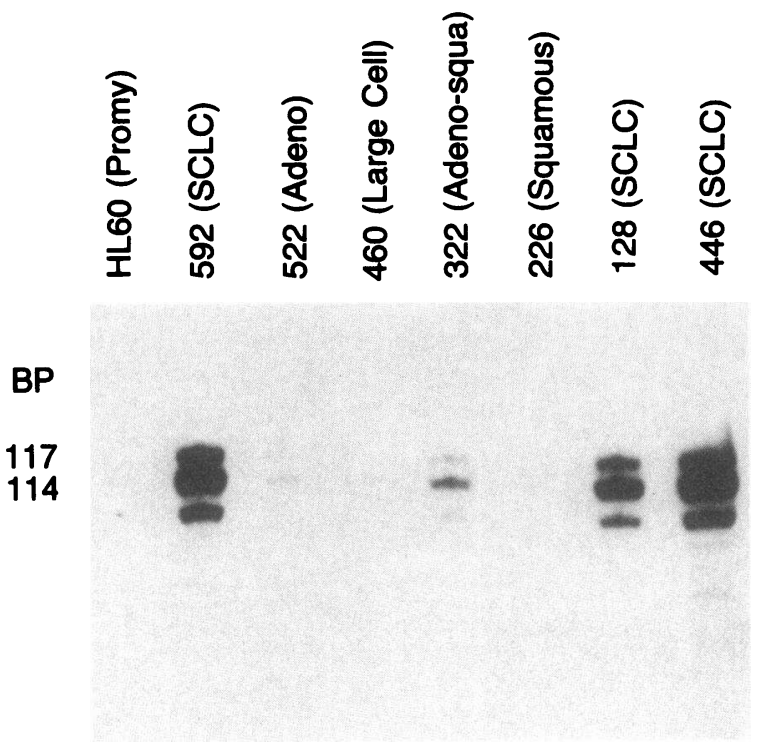

PROBE: Antisense 3' UT

Figure 6. RNAase protection assay to investigate CK-B specific expression in lung cancer cell lines. $10 \mu \mathrm{g}$ of total RNA, isolated from different cell lines as listed, were hybridized for $16 \mathrm{~h}$ with the $3^{\prime}$ untranslated anti-sense CK-B specific probe. Autoradiography was performed after RNAase digestion and 6\% denaturing acrylamide gel electrophoresis. Protection of three species at 117,114 , and 111 bp results from digestion of a few nucleotides from each end of a 115-bp region of homology. See explanation in text.
In Hind III digests, the $9 \mathrm{~kb}$ and $7.7 \mathrm{~kb}$ hybridizing human bands (Fig. $8 \mathrm{~A}$ ) were well resolved from homologous mouse sequences but the 9-kb band could not be separated from a doublet (9.3 and $8.8 \mathrm{~kb}$ ) of hybridizing hamster sequences. In Pst I digests (Fig. $8 \mathrm{~B}$ ), all four hybridizing human fragments were resolved from hybridizing bands in mouse DNA, but the 5-kb human band was not resolved from a 4.9-kb hybridizing sequence in hamster DNA. The 8.4-kb hybridizing human sequence in Bam HI digests (Fig. $8 \mathrm{C}$ ) was resolved from homologous rodent bands but the 24-kb human band intensity was low and it was poorly separated from a 22-kb hamster band.

Analysis of the panel of hybrid cell DNAs reveals that sequences hybridizing to the CK-B probe were located on two different human chromosomes (Table I). The 2.4- and 7.7-kb human Hind III bands and the 0.95- and 1.55-kb human Pst I bands always segregated concordantly and were detected only in hybrid cells that contained the 8.4-kb Bam HI human band. These CK-B hybridizing sequences, designated CK-B1, could be localized to the specific human chromosomal band $14 \mathrm{q} 32$. This localization was obtained by analysis of a group of hybrids that were isolated after fusing human fibroblasts containing a well characterized reciprocal chromosome translocation (Xq13;14q32) with Chinese hamster fibroblasts (27). Two of these hybrids retained the human $14 / \mathrm{X}$ translocation chromosome but no human CK-B1 sequences (Fig. $8 C$, lane 2) while the other three hybrids retained these CK-B1 sequences and the human $\mathrm{X} / 14$ translocation chromosome but neither an intact chromosome 14 nor the $14 / \mathrm{X}$ reciprocal translocation chromosome. Human CK-BB isoenzyme activity and the heavy chain immunoglobulin locus (IgH) (27) also cosegregated with the now designated CK-B1 sequence in these hybrids. These results permit unambiguous assignment of this CK-B gene to the same telomeric band on human chromosome 14 (14q32) previously shown to contain the IgH locus (27). This interpretation is strengthened by the fact that five independent human-mouse hybrids retain an incomplete chromosome 14 but do not contain human CKB1 sequences or IgH sequences. These hybrids, however, all express nucleoside phosphorylase, a long arm marker for this chromosome (data not shown).

In a second group of hybrids, the 2.7- and 5.0-kb human Pst I bands, and the 9-kb human Hind III band were observed to segregate concordantly to chromosome 16 (Table I). These sequences have been designated as CK-B2. The 24-kb human Bam HI band also appeared to be present in this second group of hybrids, but the weak band intensity and poor separation from homologous bands prevented unambiguous chromosomal assignment of this band. One particular somatic cell hybrid retained a chromosome 16 with a deletion of most of the long arm. A long arm marker, diaphorase-4 (16q12-q21), is not expressed in this hybrid, but a short arm marker, phosphoglycolate phosphatase (16p12-p13), was detected. This hybrid retained the active human metallothionein gene complex (28) and the CK-B2 sequence. Four other hybrids from another series retained human diaphorase-4, active metallothionein genes, and the CKB2 sequence, but lacked phosphoglycolate phosphatase activity (data not shown). These results localize the CK-B2 sequence to the region $16 \mathrm{p} 13-16 \mathrm{q} 21$.

\section{Discussion}

Over the past $10 \mathrm{yr}$ an increasingly central role has been recognized for creatine kinase in cellular metabolism. As the catalytic enzyme for the phosphocreatine shuttle, CK is considered 


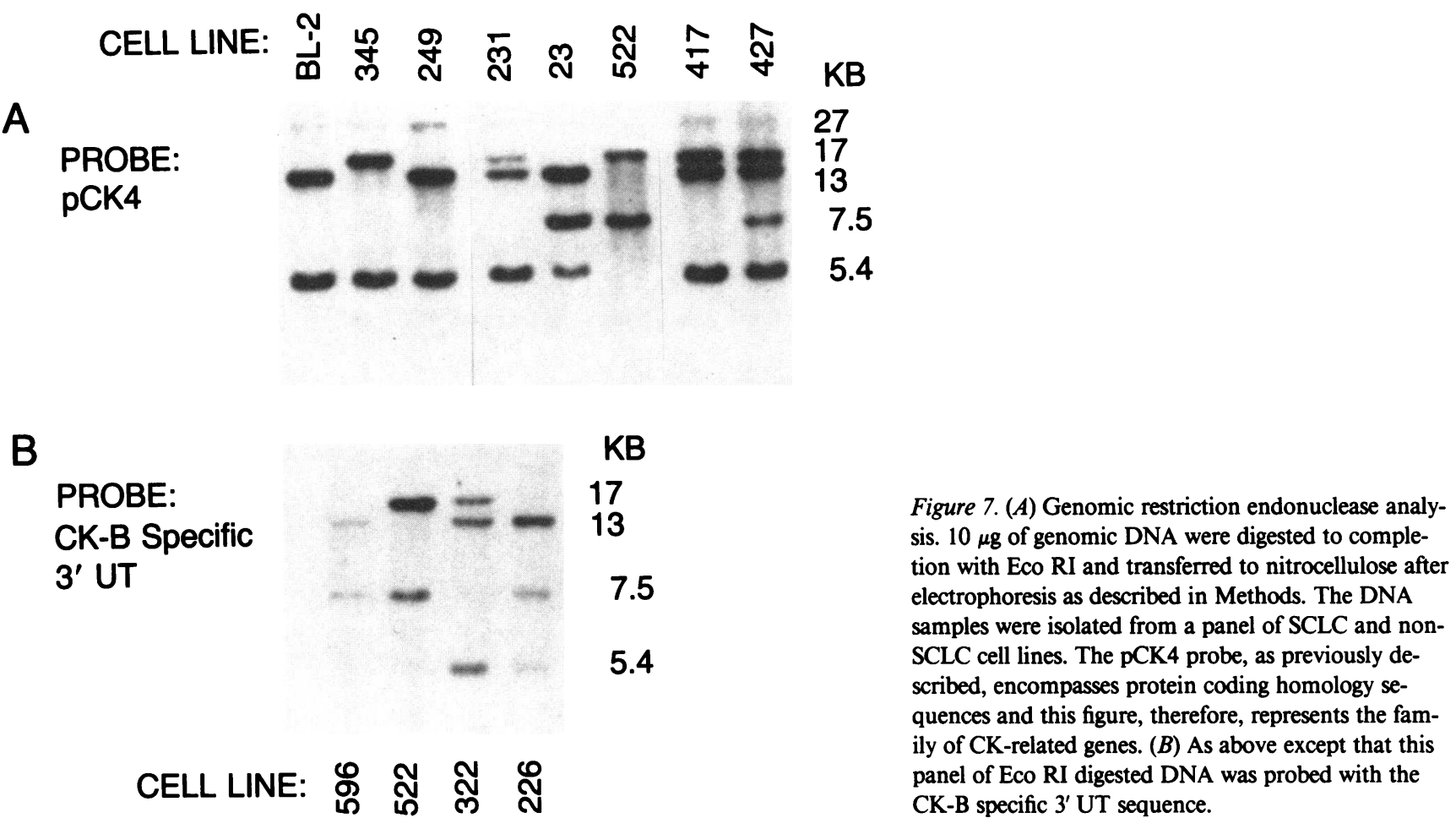

Figure 7. (A) Genomic restriction endonuclease analysis. $10 \mu \mathrm{g}$ of genomic DNA were digested to completion with Eco RI and transferred to nitrocellulose after electrophoresis as described in Methods. The DNA samples were isolated from a panel of SCLC and nonSCLC cell lines. The pCK4 probe, as previously described, encompasses protein coding homology sequences and this figure, therefore, represents the fampanel of Eco RI digested DNA was probed with the CK-B specific 3' UT sequence.

responsible for the movement of high energy phosphate bonds from the mitochondrion to sites of cellular work (1). In addition to their participation as an energy shunt for skeletal muscle and other contractile proteins (29), creatine kinases have also been implicated in certain tissues with protein and lipid synthesis (30), maintenance of ionic gradients across membranes (31), phagocytosis (32), mitotic spindle elongation (33), and as a structural protein (34).

This paper establishes the primary structure of the protein coding and $3^{\prime}$ untranslated region of the human creatine kinase$B$ gene. The translated protein encompasses 381 residues and demonstrates remarkable evolutionary conservation with amino acid homology to the rabbit CK-B cDNA in excess of $98 \%$. Although homology with the rabbit CK-M cDNA sequence is considerably less, we have observed that a nucleic acid probe subcloned from the protein coding region will cross-hybridize with human CK-M sequences. In contrast, a probe derived from the $3^{\prime} \mathrm{UT}$ region is CK-B specific. Using this CK-B specific fragment in an RNAase protection assay, the present experiments demonstrate that the elevated CK activity in SCLC is an expression of markedly increased steady-state levels of the CK transcript. Preliminary analysis of other tumors with an increased amount of CK enzyme activity also reveal marked differences in steadystate transcript levels and raises the question whether such increased expression is of metabolic consequence to the tumor.

Prior investigations have attempted to identify the functional domains of this enzyme by combining the data from biochemical experiments with more recent data that compares regions of interspecies amino acid conservation $(2,8)$. Our work, establishing the primary structure of the human CK-B cDNA, identifies a highly conserved region of amino acids flanking a cysteine residue at amino acid position 283 . This cysteine residue has been shown to be indirectly linked to the active site of the enzyme with loss of activity following modification with various thiol blocking agents $(35,36)$. The specific sites involved in the phosphate group transfer or in nucleotide binding have not been determined. Specific modification of chicken CK-MM or BB with proteinase $K$ and pronase $E$ cleaves the enzyme $\sim 50$ amino acids from the carboxyl end, generating two fragments that result in the loss of $90 \%$ enzyme activity (37). This cleavage has been determined to occur between alanine residues 328 and 329 , which is 45 residues downstream from the conserved cysteine site. Of interest, the carboxyl terminal-modified, proteolytically inactivated, enzyme is still able to establish proper subunit-subunit interactions suggesting that the subunit recognition domain is at a distance upstream from the cleaved residues. This subunit recognition domain is currently undefined, but highly conserved regions (e.g., amino acids 183-223) between both $M$ - and B-genes exist and could be of importance in such subunit interactions. The ability to generate hybrids between the BB isoenzyme of the rabbit or ox with the analogous invertebrate enzyme arginine kinase from the sea cucumber (Holothuria forskali) (38) underscores the potential functional importance of these subunit interactions.

The use of a B-specific sequence has also allowed us to explore the complex genomic pattern of the CK related family of genes. We did not observe any evidence for amplification or rearrangement of these genes in SCLC. We did, however, demonstrate that there are at least two CK-B homologous sequences in human DNA on different chromosomes. Prior chromosomal mapping of CK-B activity by starch gel electrophoresis of somatic cell hybrid lysates localized the gene to chromosome $14(39,40)$. Other authors, however, concluded that the presence of other chromosomes, in particular chromosome 17, were required in combination with chromosome 14 for CK-BB expression (41, 42). Although this latter observation was not confirmed (27) provisional assignment of a CK-B locus has also been to chromosome 17 (43). Since these are functional assays, these analyses 


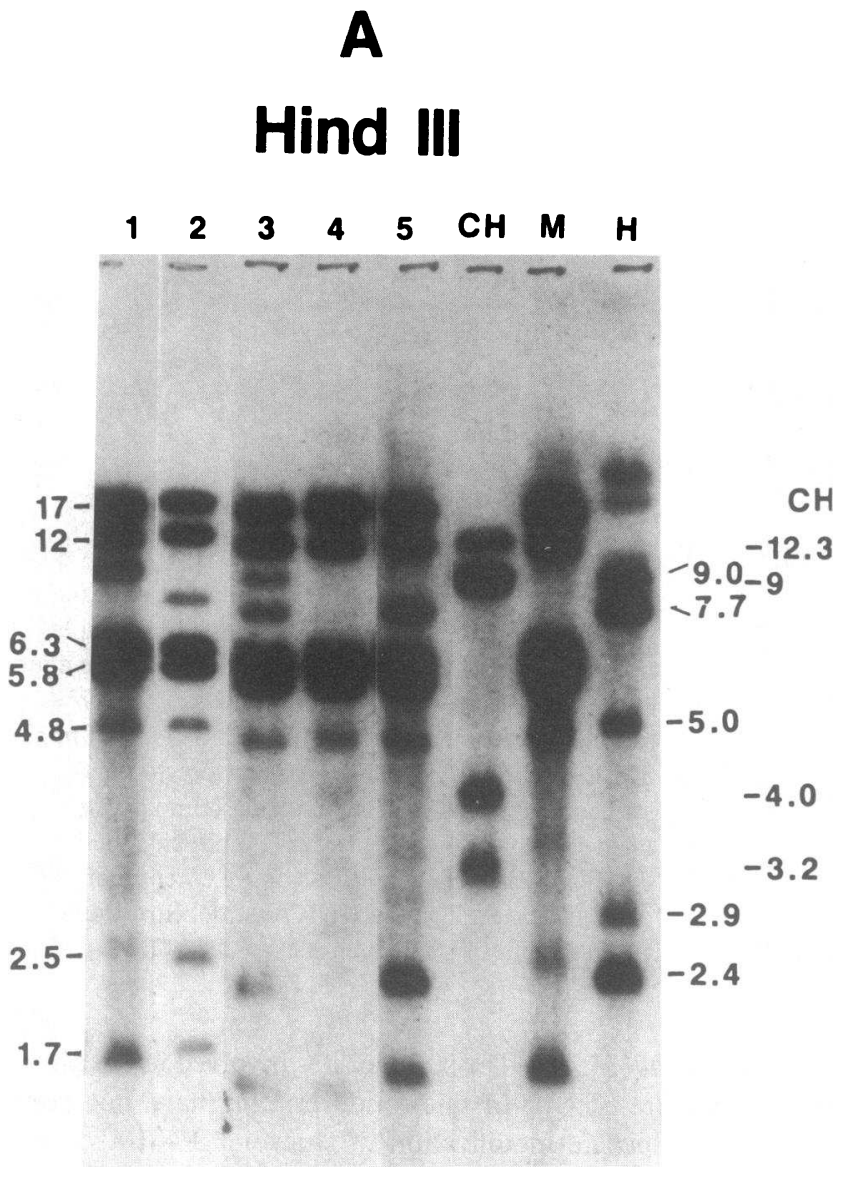

B

\section{Pst I}

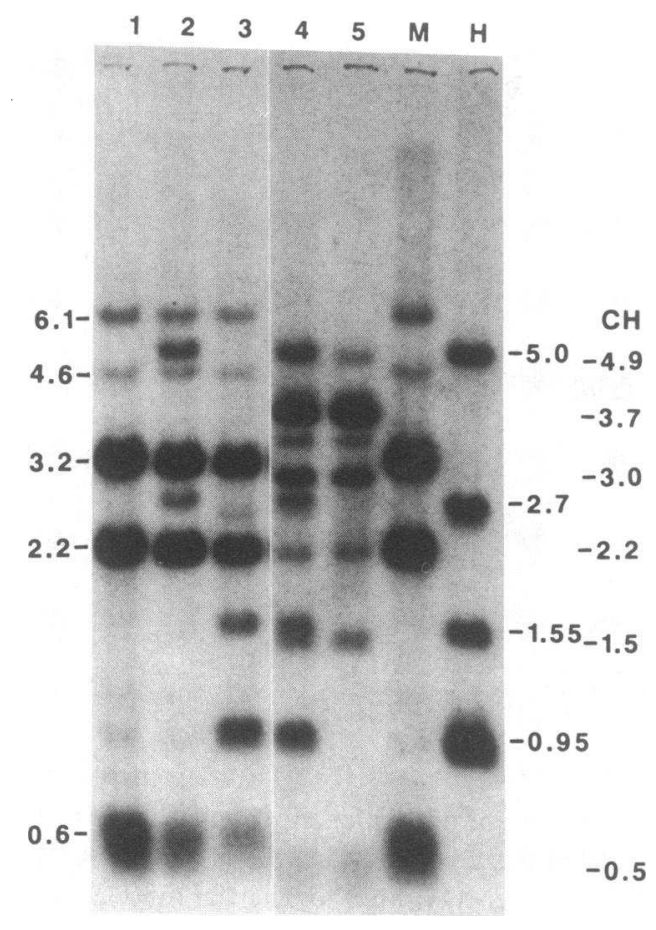

C

\section{Bam HI}

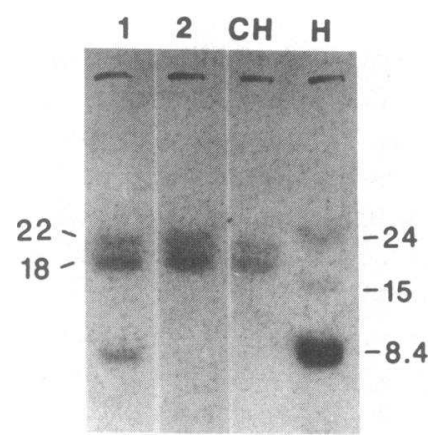

Figure 8. Southern analysis of genomic human-rodent cell hybrids and control DNAs. Genomic DNAs $(20 \mu \mathrm{g})$ were completely digested with the indicated restriction enzyme and transferred to nylon membranes after agarose electrophoresis. Hybridizations were performed with both the CK-B specific 3' UT sequence and with the near full length CK-B cDNA sequence $\mathrm{pCK} 4$, which gave a more intense signal on autoradiography. Lanes $H, M$, and $C H$ contain DNA isolated from human placenta, mouse $\mathrm{LMTK}^{-}$cells or Chinese hamster cells, respectively. (A) Hind III digests. Lanes 1-5 depict representative human-mouse hybrids which exhibit 7.7 and $2.4 \mathrm{~kb}$ human bands (lanes 2 and 5) or a $9.0 \mathrm{~kb}$ human band (lane 1 ), both series of bands (lane 3 ) or no hybridizing human bands (lane 4). Only the 7.7 and $9.0 \mathrm{~kb}$ human bands were detected when membranes were hybridized with the $3^{\prime}$ UT probe. The large ( 18 and $24 \mathrm{~kb}$ ) bands observed in lane $H$ were very weak or not detected in most digests of human DNA. The sizes (kb) of hybridizing bands are indicated along the left margin (mouse), right margin (human), and far right margin (hamster). (B) Pst I digests. Human-mouse (lanes 1-3) and human-hamster (lanes 4 and 5) hybrids exhibit 5.0 and $2.7 \mathrm{~kb}$ human bands (lane 2), 1.5 and $0.95 \mathrm{~kb}$ human bands (lane 3), both sets of bands (lane 4) or no human bands (lane 1 and 5). Only the 5.0- and $0.95-\mathrm{kb}$ human bands were detected with the 3' UT probe. Size markers are as indicated in $(A) .(C)$ Bam HI digests. Human-hamster hybrids show the presence (lane 1 ) or absence (lane 2) of the $8.4 \mathrm{~kb}$ human band. Both the $8.4 \mathrm{~kb}$ band and the weak 24-kb human band were detected with the $3^{\prime}$ UT probe. The sizes (kb) of hamster (left) and human (right) bands are shown. 
Table I. Segregation of CK-B Sequences with Specific Human Chromosomes

\begin{tabular}{|c|c|c|}
\hline \multirow[b]{2}{*}{ Human chromosomes } & \multicolumn{2}{|c|}{ \% Discordancy } \\
\hline & CK-B1 & CK-B2 \\
\hline 1 & 31 & 47 \\
\hline 2 & 48 & 53 \\
\hline 3 & 47 & 50 \\
\hline 4 & 49 & 57 \\
\hline 5 & 35 & 30 \\
\hline 6 & 17 & 43 \\
\hline 7 & 38 & 45 \\
\hline 8 & 34 & 27 \\
\hline 9 & 32 & 43 \\
\hline 10 & 41 & 50 \\
\hline 11 & 50 & 34 \\
\hline 12 & 26 & 35 \\
\hline 13 & 30 & 30 \\
\hline 14 & $0^{*}$ & 34 \\
\hline 15 & 22 & 50 \\
\hline 16 & 29 & 0 \\
\hline 17 & 46 & 55 \\
\hline 18 & 35 & 45 \\
\hline 19 & 31 & 43 \\
\hline 20 & 27 & 34 \\
\hline 21 & 30 & 45 \\
\hline 22 & 50 & 50 \\
\hline $\mathbf{X}$ & 46 & 48 \\
\hline
\end{tabular}

The presence of human sequences hybridizing with a human CK-B specific cDNA probe is correlated with the presence or absence of specific human chromosomes in $\mathbf{3 6}$ human-hamster and 38 humanmouse hybrid cell lines in column 1 or 6 human-hamster and 38 human-mouse hybrids in column 2. Discordancy represents either the presence of a specific human chromosome in the absence of human CK-B hybridizing sequences or the presence of these sequences despite the absence of the chromosome in that hybrid. The percent discordancy represents the sum of these numbers divided by the total number of hybrids examined. The chromosome giving the lowest discordancy (i.e., $0 \%$ ) contains the CK-B specific sequence. Column 1 indicates discordancy with the 2.4- and 7.7-kb human Hind III bands, the 0.95- and 1.55-kb human Pst I bands, and the $8.4 \mathrm{~kb}$ human Bam HI band (i.e., CK-B1 sequence). Column 2 indicates discordancy with the 9.0 kb human Hind III and the 2.7 and $5.0 \mathrm{~kb}$ human Pst I bands (i.e., CK-B2).

* There were no discordancies between hybrid cells retaining chromosome band $14 \mathrm{q} 32$ and CK-B1 hybridizing sequences, but there were 10 discordancies (14\%) involving portions of chromosome 14 not containing this band (see text).

may be subject to influences of outside regulatory forces at the transcriptional or posttranscriptional level. In addition, such analyses would not detect genes that were not functional in the hybrid environment. Our studies establish the mapping of a CKB gene to chromosome $14 \mathrm{q} 32$, and have also found evidence for a second CK-B gene or gene-related sequence on chromosome 16. B-subunit:B-subunit mixing experiments (44) and high resolution two-dimensional gel electrophoresis (45) have suggested the presence of two functional CK-B genes in certain species. In addition there is recent evidence for sequence heterogeneity among chicken CK-B cDNA clones in their $3^{\prime}$ untranslated and coding regions again suggesting either the presence of two distinct genes or the occurrence of alternative processing (46).

Since it is known that the CK-B gene on chromosome 14, which we call CK-B1, is functional in rodent-human hybrids, the precise role and functional activity of the CK-B gene on chromosome 16 (here designated CK-B2) needs to be established. While it is conceivably only a CK-B-related gene or pseudogene, it is also possible that it represents a CK-B enzyme activated during ontogeny in a regulated fashion, distinct from activation of CK-B1. We have recently cloned the CK-B1 locus on chromosome 14 and have observed the appropriate organization of an active gene. It will be of interest to use this clone and the two independent, high frequency Eco RI polymorphism sites that we have identified to explore allelic distribution and activation of this locus in neuroendocrine tumors.

\section{Acknowledgments}

We thank Dr. Philip Leder for the human placental genomic library, Jane Trepel for providing HL-60 cell cultures, and Marion Nau and Mark Levitt for some of the DNA and RNA samples used in this study. We thank Dr. John D. Minna for advice, encouragement, and critical review of the manuscript.

\section{References}

1. Bessman, S. P. 1985. The creatine-creatine phosphate energy shuttle. Annu. Rev. Biochem. 54:831-862.

2. Pickering, L., H. Pang, K. Biemann, H. Munro, and P. Schimmel. 1985. Two tissue-specific isozymes of creatine kinase have closely matched amino acid sequences. Proc. Natl. Acad. Sci. USA. 82:2310-2314.

3. Roman, D., J. Billadello, J. Gordon, A. Grace, B. Sobel, and A. Strauss. 1985. Complete nucleotide sequence of dog heart creatine kinase mRNA: Conservation of amino acid sequence within and among species. Proc. Natl. Acad. Sci. USA. 82:8394-8398.

4. Rosenberg, U. B., G. Kunz, A. Frischauf, H. Lehrach, R. Mahr, H. M. Eppenberger, and J. Perriard. 1982. Molecular cloning and expression during myogenesis of sequences coding for M-creatine kinase. Proc. Natl. Acad. Sci. USA. 79:6589-6592.

5. Schweinfest, C. W., R. W. Kwiatkowski, and R. P. Dottin. 1982. Molecular cloning of a DNA sequence complementary to creatine kinase M mRNA from chickens. Proc. Natl. Acad. Sci. USA. 79:4997-5000.

6. West, B. L., P. C. Babbitt, B. Mendez, and J. D. Baxter. 1984. Creatine kinase protein sequence encoded by a cDNA made from Torpedo Californica electric organ mRNA. Proc. Natl. Acad. Sci. USA. 81: 7007-7011.

7. Benfield, P. A., R. A. Ziven, L. S. Miller, R. Sowder, G. W. Smythers, L. Henderson, S. Oroszian, and M. L. Pearson. 1984. Isolation and sequence analysis of cDNA clones coding for rat skeletal muscle creatine kinase. J. Biol. Chem. 259:14979-14984.

8. Ordahl, C. P., G. L. Evans, T. A. Cooper, G. Kunz, and J. Perriard. 1984. Complete cDNA-derived amino acid sequence of chick muscle creatine kinase. J. Biol. Chem. 259:15224-15227.

9. Gazdar, A. F., M. H. Zweig, D. N. Carney, A. C. Van Steirteghen, S. B. Baylin, and J. D. Minna. 1981. Levels of creatine kinase and its BB isoenzyme in lung cancer specimens and cultures. Cancer Res. 41: 2773-2777.

10. Carney, D. N., A. F. Gazdar, G. Bepler, J. G. Guccion, P. J. Marangos, T. W. Moody, M. H. Zweig, and J. D. Minna. 1985. Establishment and identification of small cell lung cancer cell lines having classic and variant features. Cancer Res. 45:2913-2923.

11. Gazdar, A. F., and D. N. Carney. 1984. Endocrine properties of small cell carcinoma of the lung. In The Endocine Lung in Health and 
Disease. K. L. Becker, and A. F. Gazdar, editors. W. B. Saunders and Co., Philadelphia. 501-508.

12. Sausville, E. A., A. M. Lebacq-Verheyden, E. R. Spindel, F. Cuttitta, A. F. Gazdar, and J. F. Battey. 1986. Expression of the gastrinreleasing peptide gene in human small cell lung cancer. Evidence for alternative processing resulting in three distinct mRNAs. J. Biol. Chem. 261:2451-2457.

13. Cooper, T. A., and C. P. Ordahl. 1985. A single cardiac troponin $\mathrm{T}$ gene generates embryonic and adult isoforms via developmentally regulated alternate splicing. J. Biol. Chem. 260:11140-11148.

14. Sanger, F., S. Nicklen, and A. R. Coulson. 1977. DNA sequencing with chain-terminating inhibitors. Proc. Natl. Acad. Sci. USA. 74:54635467.

15. Messing, J. 1983. New M13 vectors for cloning. Methods Enzymol. 101:20-78.

16. Davis, L. G., M. D. Dibner, and J. F. Battey. 1986. Preparation of insert for M13 cloning by successive BAL 31 exonuclease deletion. In Basic Methods in Molecular Biology. L. G. Davis, M. D. Dibner, and J. F. Battey, editors. Elsevier/North Holland, Amsterdam. 244-248.

17. Polsky, F., M. H. Edgell, J. G. Seidman, and P. Leder. 1978. High capacity gel preparative electrophoresis for purification of fragments of genomic DNA. Anal. Biochem. 87:397-410.

18. Chirgwin, J., A. Przybyla, R. MacDonald, and W. Rutter. 1979. Isolation of biologically active ribonucleic acid from sources enriched in ribonucleases. Biochemistry. 18:5294-5299.

19. Aviv, H., and P. Leder. 1972. Purification of biologically active globin messenger RNA by chromatography on oligothymidylic acid-cellulose. Proc. Natl. Acad. Sci. USA. 69:1408-1413.

20. Southern, E. M. 1975. Detection of specific sequences among DNA fragments separated by gel electrophoresis. J. Mol. Biol. 98:503517.

21. Lehrach, H., D. Diamond, J. M. Wozney, and H. Boedtker. 1977. RNA molecular weight determination by gel electrophoresis under denaturing conditions, a critical reexamination. Biochemistry. 16:47434751.

22. Rigby, P. W. J., M. Dieckmann, C. Rhodes, and P. Berg. 1977. Labelling deoxyribonucleic acid to high specific activity in vitro by nick translation with DNA polymerase I. J. Mol. Biol. 113:237-251.

23. Melton, D. A., P. A. Krieg, M. R. Rebagliati, T. Maniatis, K. Zinn, and M. R. Green. 1984. Efficient in vitro synthesis of biologically active RNA and RNA hybridization probes from plasmids containing a bacteriophage SP6 promoter. Nucleic Acids Res. 12:7035-7056.

24. Myers, R. M., Z. Larin, and T. Maniatis. 1985. Detection of single base substitutions by ribonuclease cleavage at mismatches in RNA: DNA duplexes. Science (Wash. DC). 230:1242-1246.

25. Winter, E., F. Yamamoto, C. Almoguera, and M. Perucho. 1985. A method to detect and characterize point mutations in transcribed genes: Amplification and over expression of the mutant $\mathrm{c}-\mathrm{Ki}$-ras allele in human tumor cells. Proc. Natl. Aead. Sci. USA. 82:7575-7579.

26. McBride, O. W., P. A. Hieter, G. F. Hollis, D. Swan, M. C. Otey, and P. Leder. 1982. Chromosomal location of human kappa and lambda immunoglobulin light chain constant region genes. J. Exp. Med. 155: 1480-1490.

27. McBride, O. W., J. Battey, G. F. Hollis, D. C. Swan, U. Siebenlist, and $P$. Leder. 1982. Localization of human variable anu constant region immunoglobulin heavy chain genes on subtelomeric band q32 of chromosome 14. Nucleic Acids Res. 10:8155-8170.

28. Schmidt, C. J., D. H. Hamer, and O. W. McBride. 1984. Chro- mosomal location of human metallothionein genes: Implications for Menkes' disease. Science (Wash. DC). 224:1104-1106.

29. Tombes, R. M., and B. M. Shapiro. 1985. Metabolic channeling: A phosphoryl creatine shuttle to mediate high energy phosphate transport between sperm mitochondrion and tail. Cell. 41:325-334.

30. Carpenter, C. L., C. Mohan, and S. P. Bessman. 1983. Inhibition of protein and lipid synthesis in muscle by 2,4-dinitrofluorobenzene, an inhibitor of creatine phosphokinase. Biochem. Biophys. Res. Commun. 111:884-889.

31. Levitsky, D. O., T. S. Levchenko, V. A. Saks, V. G. Sharov, and V. I. Smirnov. 1978. The role of creatine phosphokinase in supplying energy for the calcium pump system of heart sarcoplasmic reticulum. Membr. Biochem. 2:81-86.

32. Loike, J. D., V. F. Kozler, and S. C. Silverstein. 1979. Increased ATP and creatine phosphate turnover in phagocytosing mouse peritoneal macrophage. J. Biol. Chem. 254:9558-9564.

33. Cande, W. Z. 1983. Creatine kinase role in anaphase chromosome movement. Nature (Lond.). 304:557-558.

34. Ottaway, J. H. 1967. Evidence for binding of cytoplasmic creatine kinase to structural elements in heart muscle. Nature (Lond.). 215:521522.

35. Mahowald, T. A., E. A. Noltmann, and S. A. Kuby. 1962. Studies on adenosine triphosphate transphosphorylases III. Inhibition studies. J. Biol. Chem. 237:1555.

36. Smith, D. J., and G. L. Kenyon. 1974. Non-essentiality of the active sulphydryl group of rabbit muscle creatine kinase. J. Biol. Chem. 249:3317.

37. Lebherz, H. G., T. Burke, J. E. Shackelford, J. E. Strickler, and K. J. Wilson. 1986. Specific proteolytic modification of creatine kinase isoenzymes. Implication of c-terminal involvement in enzyme activity but not in subunit-subunit recognition. Biochem. J. 233:51-56.

38. Watts, D. C., B. Focant, B. Moreland, and R. L. Watts. 1972. Formation of a hybrid enzyme between echinoderm arginine kinase and mammalian creatine kinase. Nat. New Biol. 237:51.

39. Chern, C. J., P. Tan, and H. Park. 1980. Chromosomal mapping of human creatine kinase (brain type) using human-rodent somatic cell hybrids. Cytogenet. Cell Genet. 27:232-237.

40. Weil, D., N. Van Cong, M. Gross, C. Foubert, and J. Frezel. 1980. Localisation du gene de la creatine kinase BB sur le chromosome 14 par l'analyse des hybrides homme-rongeur. Ann. Genet. 23:150-154.

41. Povey, S., M. Inwood, A. Tanyar, and M. Bobrow. 1979. The expression of creatine kinase isozymes in human cultured cells. Ann. Hum. Genet. (Lond.). 43:15-25.

42. Donald, L. J., H. S. Wang, and J. L. Hamerton. 1982. Are there additional CKBB loci? Cytogenet. Cell Genet. 32:267-268.

43. McKusick, V. 1986. The human gene map. Clin. Genetics. 29: 554.

44. Eppenberger, M. E., H. M. Eppenberger, and N. O. Kaplan. 1967. Evolution of creatine kinase. Nature (Lond.). 214:239.

45. Rosenberg, U. B., H. M. Eppenberger, and J.-C. Perriard. 1981. Occurrence of heterogeneous forms of the subunits of creatine kinase in various muscle and nonmuscle tissues and their behaviour during myogenesis. Eur. J. Biochem. 116:87-92.

46. Hossle, J. P., U. B. Rosenberg, B. Schafer, H. M. Eppenberger, and J.-C. Perriard. 1986. The primary structure of chicken B-creatine kinase and evidence for heterogeneity of its mRNA. Nucleic Acids Res. 14:1449-1463. 